\title{
Enhancement of Biohydrogen Production via Thermophilic Cell Culture Immobilized on Glass Beads and Raschig Rings of Different Sizes in a Packed Bed Reactor
}

doi: 10.15255/CABEQ.2014.2082

\author{
Original scientific paper \\ Received: July 17, 2014 \\ Accepted: November 26, 2015
}

\author{
E. A. Pekguzel, T. K. Gundogdu, and N. Azbar* \\ Ege University, Bioengineering Department, 35100, Bornova-Izmir/Turkey
}

\begin{abstract}
In this study, two different types of support material of different size, namely glass bead and Raschig ring, packed in a plug flow reactor, were used in order to compare their biohydrogen production performances with that of a CSTR reactor. All experiments were conducted under thermophilic conditions $\left(55^{\circ} \mathrm{C} \pm 2{ }^{\circ} \mathrm{C}\right)$. The best results in terms of volumetric hydrogen productivity were obtained with large-sized glass beads (LSG: $2.98 \mathrm{~L} \mathrm{H}_{2} \mathrm{~L}^{-1}$ bioreactor day ${ }^{-1}$ ) at $3 \mathrm{~h}$ hydraulic retention time (HRT). Raschig ring materials were able to produce $42 \%$ less hydrogen than glass beads. Hydrogen productivity in the CSTR type reactor was $0.5 \mathrm{~L} \mathrm{H}_{2} \mathrm{~L}^{-1}$ bioreactor day-1 In conclusion, the immobilized cell type bioreactor configuration provided 7-11 times better results in terms of volumetric hydrogen production values compared to the CSTR reactor. It was demonstrated that both glass beads and Raschig ring type support materials, which are readily available, showed promising results for hydrogen production.
\end{abstract}

Key words:

biohydrogen, immobilization, mixed culture, glass bead, raschig ring

\section{Introduction}

Energy security is an important issue in the calendar of all developed and developing countries. As much as $80 \%$ of the global energy demand is based on fossil fuels ${ }^{1}$. Man kind does not only face the risk of a global energy crisis, but also suffers from serious environmental disasters caused by extensive use of fossil fuels ${ }^{2}$. Global warming caused by $\mathrm{CO}_{2}$ emissions from fossil-based fuels also forces national economies to seek environmentally friendly energy alternatives. In this context, hydrogen, which has zero $\mathrm{CO}_{2}$ emission, seems very promising ${ }^{3-5}$. Among the alternative hydrogen production technologies, such as thermochemical and electrochemical methods, which are highly energy-intensive processes, hydrogen production via either dark fermentation and/or photo-fermentation seems very advantageous and sustainable. It is well known that the natural environment accommodates various microorganisms capable of producing hydrogen, finally available for higher scale engineering applications $^{6-10}$. On the other hand, hydrogen production via dark fermentation using a mixed consortium has many advantages over pure cultures, since almost all organic material, especially waste organics, are amenable for this purpose ${ }^{3}$. Concerning substrates

"Corresponding authors: e-mail address: nuri.azbar@ege.edu.tr, phone: +90 2323884955 (31) fax : + 902323884955 ,

e-mail address: eaksoyek@hotmail.com,keskin.tugba@gmail.com used for hydrogen production in the literature, substrates rich in carbohydrate such as glucose, sucrose, starch and cellulose seem to be the most common. In this study, sucrose was chosen as a reference substrate since it is vastly available (150 million tons) ${ }^{11}$. Furthermore, our literature survey indicated that suspended cell culture systems, such as CSTR type bioreactors, are the most commonly reported systems for the production of $\mathrm{H}_{2}$, although this reactor configuration has inherent operational problems, such as cell washout, lack of stability and robustness under severe loading conditions, etc. ${ }^{5,12}$. On the other hand, immobilized bioreactors can achieve higher hydrogen production with smaller reactor volumes,as well as provide a more stable production, which is more resistant to the shock loadings and toxicity ${ }^{2,13,14}$.

In this study, immobilized biohydrogen production using different sizes of support materials (small-size Raschig rings (SSR), large-size Raschig rings (LSR), small-size glass beads (SSG) and large-size glass beads (LSG)) were compared under thermophilic conditions with suspended cell cultures operated with CSTR under identical conditions. Raschig rings and glass beads were chosen as the support matrices because of their good porous structure and homogeneous composition. Apart from the studies available in the literature ${ }^{15}$, the aim of this study was to test the feasibility of using glass materials of different sizes for hydrogen production under thermophilic conditions at significantly high 
substrate concentrations. Since there are very few studies available involving fermentation using immobilized cell culture systems for biohydrogen production, further investigation is warranted.

\section{Materials and method}

\section{Hydrogen-producing sludge}

The anaerobic inoculum was obtained from an anaerobic bioreactor operating at a yeast factory in Izmir, Turkey. The microbial culture was the same culture used in another study in our laboratory. The detailed analyses of the microbial culture were discussed briefly in that study. The results indicated that the dominant culture in the anaerobic sludge was Clostridium species $^{16}$. The hydrogen-producing sludge was a mixture of the acidogenic and methanogenic reactor effluent with an equal volumetric ratio of $1 / 1$. The sludge was used after heat treatment at $105{ }^{\circ} \mathrm{C}$ for 5 minutes by autoclaving to eliminate the methanogenic bacteria and enrich the hydrogen-producing organisms, especially Clostridium species. The $\mathrm{pH}$, volatile suspended solids (VSS) and total suspended solids (TSS) concentrations of the inoculum were $6.4,17 \mathrm{~g} \mathrm{~L}^{-1}$ and $32 \mathrm{~g} \mathrm{~L}^{-1}$, respectively ${ }^{2}$.

\section{Medium composition}

Sucrose (MERCK) was used as the limiting carbon substrate for hydrogen fermentation. In all cases, the medium contained $10 \mathrm{~g} \mathrm{~L}^{-1}$ sucrose, while the macro- and micro-elements in $\mathrm{g} \mathrm{L}^{-1}$ were; $\mathrm{NaHCO}_{3}$ (1.25); $\mathrm{NH}_{4} \mathrm{Cl}$ (1.25); $\mathrm{K}_{2} \mathrm{HPO}_{4}$ (0.25), $\mathrm{KH}_{2} \mathrm{PO}_{4}(0.25), \mathrm{CaCl}_{2} \cdot 2 \mathrm{H}_{2} \mathrm{O}(0.66), \mathrm{NiSO}_{4}$ (0.032), $\quad \mathrm{MgSO}_{4} \cdot 7 \mathrm{H}_{2} \mathrm{O} \quad(0.32), \quad \mathrm{FeCl}_{2} \cdot 4 \mathrm{H}_{2} \mathrm{O}$ (0.0245), $\mathrm{Na}_{2} \mathrm{MoO}_{4} \cdot 2 \mathrm{H}_{2} \mathrm{O}(0.0144), \mathrm{ZnCl}_{2}(0.023)$, $\mathrm{CoCl}_{2} \cdot 6 \mathrm{H}_{2} \mathrm{O} \quad(0.021), \quad \mathrm{CuCl}_{2} \cdot 2 \mathrm{H}_{2} \mathrm{O} \quad(0.0112)$, $\mathrm{MnCl}_{2} \cdot 4 \mathrm{H}_{2} \mathrm{O}(0.03)$, yeast extract $(0.05)$, L-cystein $(0.5)$ as given in Keskin et al. ${ }^{2}$

\section{Support matrices}

Each bioreactor was filled separately with glass beads and Raschig rings as an immobilization material, respectively. Although Raschig rings are favorable packing materials for enzyme production processes and fluidized bed configurations, especially in industrial applications, glass beads are not regularly used in dark fermentative hydrogen production studies. In this study, the Raschig rings were made from trash glass by cutting different sizes of glass pipettes into equal pieces in the glass atelier of the department. Small-size Raschig ring (SSR) material had a height of $1.5 \mathrm{~cm}$ and diameter of $0.8 \mathrm{~cm}$, whereas large-size Raschig ring (LSR) material had a height of $1 \mathrm{~cm}$ and diameter of $1 \mathrm{~cm}$. SS and LS glass beads had a diameter of $0.3 \mathrm{~cm}$ and $0.5 \mathrm{~cm}$, respectively. The results of BET analysis of the packing materials were as follows: $8.37 \cdot 10^{-4} \mathrm{~m}^{2} \mathrm{~g}^{-1}$ (SSR), $2.91 \cdot 10^{-4} \mathrm{~m}^{2} \mathrm{~g}^{-1}$ (LSR), $0.58 \mathrm{~m}^{2} \mathrm{~g}^{-1}$ (SSG) and $0.33 \mathrm{~m}^{2} \mathrm{~g}^{-1}$ (LSG), respectively.

\section{Experimental setup of the immobilized bioreactors for biohydrogen production}

The experiments were conducted by an up-flow anaerobic plug flow reactor packed with immobilization materials. The experimental apparatus of the study is shown in Figure 1. This system consisted of an immobilized bioreactor (height of $30 \mathrm{~cm}$ and a diameter of $4.5 \mathrm{~cm}$ ), peristaltic pump, and a heating system. Each reactor was filled with different immobilization material as mentioned above. The total volume of each reactor was $330 \mathrm{~mL}$. Upon filling the reactors with immobilization material, the working volumes were measured to be $270 \mathrm{~mL}$ (LSR), $135 \mathrm{~mL}$ (LSG), $135 \mathrm{~mL}$ (SSG) and 310 (SSR) $\mathrm{mL}$, respectively. Thermophilic conditions $\left(55^{\circ} \mathrm{C} \pm 2{ }^{\circ} \mathrm{C}\right)$ were provided with a coiled silicon tube heat exchanger. The hydrogen production was monitored on the basis of HRT (Hydraulic Retention Time) and OLR (Organic Loading Rate). The
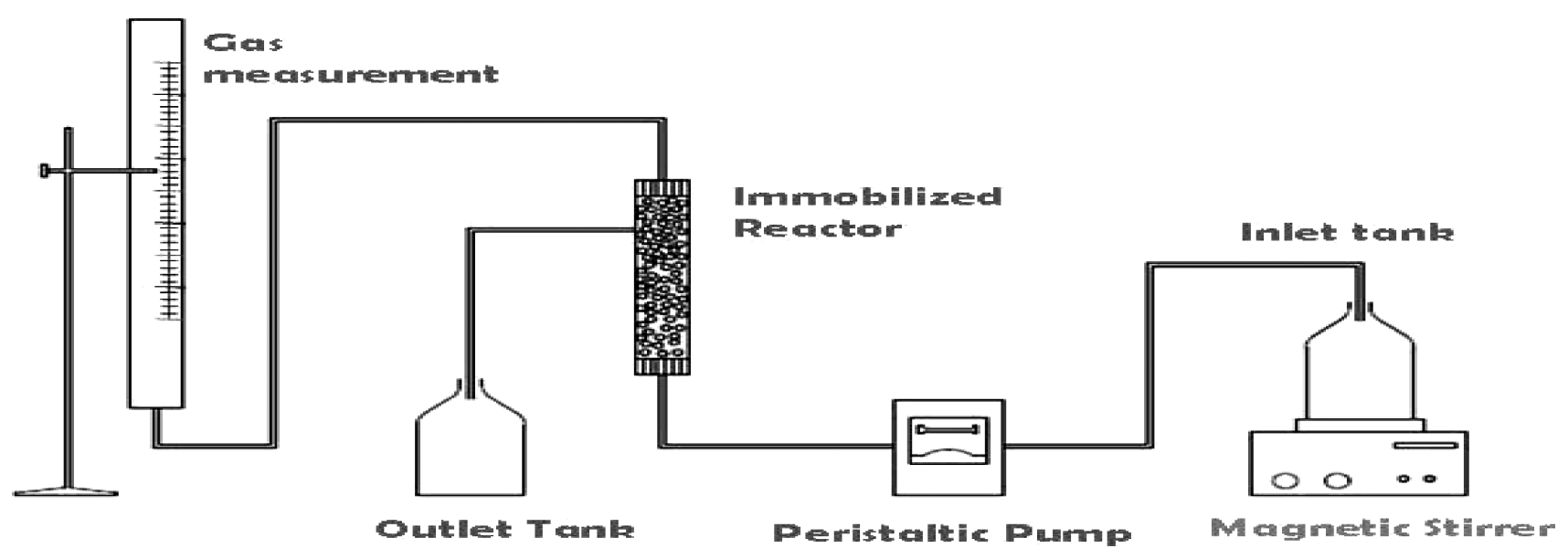

Fig. 1 - Experimental setup of the immobilized cell bioreactors 
HRT decreased as the hydrogen production values showed stable production values, and a reasonable coefficient of variation as an indication of pseudosteady-state conditions. Flow rate of the fresh feed to each bioreactor was adjusted by considering the working volume of each reactor in order to provide predetermined HRT values between 1.5 and $24 \mathrm{~h}$. The biogas produced was taken from the top of the reactor with a wet-type gas meter. The composition of the gas was measured by GC on a daily basis.

In order to compare the hydrogen production performance of immobilized and suspended cell bioreactor configurations, a separate CSTR was operated under identical conditions with the same inoculum. The CSTR bioreactor characteristics and operation settings have been described in Keskin et $a l^{2}$ The reactors were continuously operated for the hydrogen fermentation at varying range of hydraulic retention times (HRT) in decreasing order (24h- 12 h- 6 h- 3 h- 1.5 h). Operational parameters, such as residual sucrose, $\mathrm{COD}, \mathrm{pH}$, volatile fatty acids (VFA) and suspended solids were monitored daily for all reactors.

\section{Cell cultivation and cell immobilization}

Five hundred milliliters of the aforementioned medium together with the anaerobic inoculum $\left(17 \mathrm{~g} \mathrm{VSS} \mathrm{L}^{-1}\right)$ were circulated with a peristaltic pump through the packed bed bioreactors at $0.5 \mathrm{~h}$ HRT for at least one day (corresponding to 48 circles) for cultivation and immobilization of cells. Circulation was stopped when the highest immobilization ratio was obtained.

\section{Analytical methods}

Gas chromatography (GC) (6890N Agilent) equipped with a thermal conductivity detector and Hayesep D 80/100 packed column was used to analyze the $\mathrm{H}_{2}$ content in the headspace. Injector, detector, and column temperatures were kept at $120^{\circ} \mathrm{C}$, $140{ }^{\circ} \mathrm{C}$, and $35^{\circ} \mathrm{C}$, respectively. Argon was used as the carrier gas at a flow rate of $20 \mathrm{~mL} \mathrm{~min}$.

Samples were centrifuged at $10000 \mathrm{rpm}$ for 10 minutes before each analysis. Chemical oxygen demand (COD) and suspended solids (SS) were measured according to the standard methods (APHA). Total sugar concentration was estimated as glucose by the phenol sulfuric acid method. Volatile fatty acids (acetate, propionate, butyrate, isobutyrate, isovalate, valate, isocaprionate, caprionate and heptanoic acid) and alcohols (ethanol, acetone and butanol) in the mixed liquor were analyzed using a GC (6890N Agilent) equipped with a flame ionization detector and DB-FFAP $30 \mathrm{~m}-0.32 \mathrm{~mm}-0.25 \mathrm{~mm}$ capillary column (J\&WScientific) as reported in Azbar et al. ${ }^{16}$

\section{SEM analysis}

SEM analyses were carried out with Philips XL-30S FEG / FEI Quanta250 FEG brand of SEM scanning electron microscope after coating each sample with gold/-palladium using Magnetron Sputter Coating Instrument at Izmir Institute of Technology.

\section{Results and discussions}

In this study, the aim was to enhance dark fermentative biohydrogen production via immobilized cell reactor configuration in packed bed reactors. For this purpose, four different immobilization glass materials (LSR, SSR, SSG and LSG) were comparatively tested under conditions of continuous operation. The mixed culture used as inoculum throughout the study was thermally pretreated to prepare and enrich the hydrogen-producing bacteria in the mixed consortium, as suggested by several reports $^{6,8,12,17-19}$.

Complex substrates such as cellulose,lignocellulosic materials, and starch as in their raw formare not suitable for the fermentative production of hydrogen because of their nature. However, thermo-chemical and/or physical-chemical pretreatment can be applied in order to increase biodegradability of these substrates. Operating temperature and $\mathrm{pH}$ values are important parameters for dark fermentative hydrogen production. Many of the studies on producing biohydrogen were carried out at mesophilic conditions, while on the other hand, several reports indicated that thermophilic temperature conditions resulted in higher hydrogen yields ${ }^{20}$. Therefore, $55{ }^{\circ} \mathrm{C}$ was chosen as the best temperature for this project.

Organic acid synthesis during dark fermentation results in a decrease in the $\mathrm{pH}$ of the fermentation broth. The $\mathrm{pH}$ drop must be controlled to prevent any shift in metabolic pathways towards solvent production or any other hydrogen-consuming intermediate such as propionate ${ }^{21}$. Generally, the $\mathrm{pH}$ range of biohydrogen production with dark fermentation is between 5.0 and $6.5^{22}$. Although there was no $\mathrm{pH}$ control system in our immobilized bioreactors in this study, the $\mathrm{pH}$ values remained stable at around $5.0-5.5$ because of the buffering capacity of the influent.

HRT values gradually decreased from $24 \mathrm{~h}$ to $1.5 \mathrm{~h}$ upon successfully completing cell immobilization on the support materials used in this study. The influent sucrose concentration was kept constant at $10 \mathrm{~g}$ sucrose $\mathrm{L}^{-1}$. Figure 2 shows the organic loading rates (OLR) for each bioreactor and as shown in the graphics, OLR values decreased expo- 


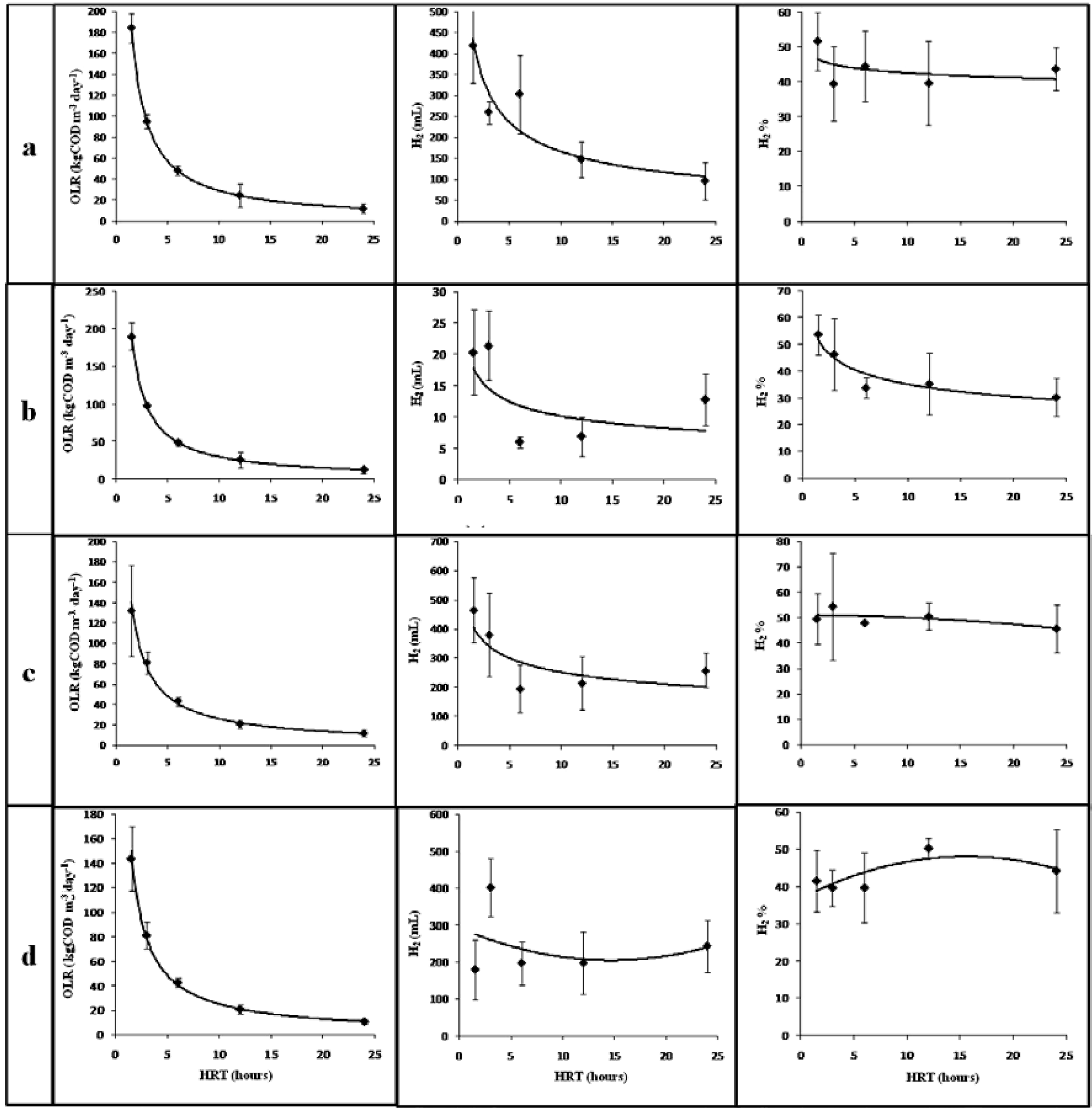

Fig. 2 - Results of the immobilized cell plug flow bioreactors (a) Graph shows the (OLR), $\mathrm{H}_{2}(\mathrm{~mL})$ and $\mathrm{H}_{2} \%$ for small-size Raschig ring packing (b) Graph shows the (OLR), $H_{2}(\mathrm{~mL})$ and $\mathrm{H}_{2} \%$ for large-size Raschig ring packing (c) Graph shows the $(\mathrm{OLR}), \mathrm{H}_{2}(\mathrm{~mL})$ and $\mathrm{H}_{2} \%$ for small-size glass beads packing (d) Graph shows the (OLR), $\mathrm{H}_{2}(\mathrm{~mL})$ and $\mathrm{H}_{2} \%$ for large-size glass beads packing

nentially with increasing HRT values. The efficient OLR values determined from the bioreactors were $190 \mathrm{~kg} \mathrm{COD} \mathrm{m}^{-3} \mathrm{~d}^{-1}$ for LSR, and $144 \mathrm{~kg} \mathrm{COD} \mathrm{m}^{-3} \mathrm{~d}^{-1}$ for LSG immobilized bioreactors at $1.5 \mathrm{~h}$ of HRT.

\section{Cell immobilization}

Successful cell immobilization was achieved. Figure 3 shows the cell immobilization ratio, which was $72 \%$ and $62 \%$ for SSR and LSR respectively, whereas $92 \%$ and $89 \%$ of the biomass had attached to the SSG and LSG. The higher immobilization percentage means higher microorganism concentrations on packing materials. The microorganism concentrations on small-size Raschig rings and smallsize glass beads are higher than those on large-size of Raschig rings and glass beads. The surface areas of the small-size packing materials are higher than that of the large-size packing materials, meaning that there is more space for the microorganisms to attach. SEM imaging also proved that cell immobilization was successful as shown in Figures 4 and 5. 

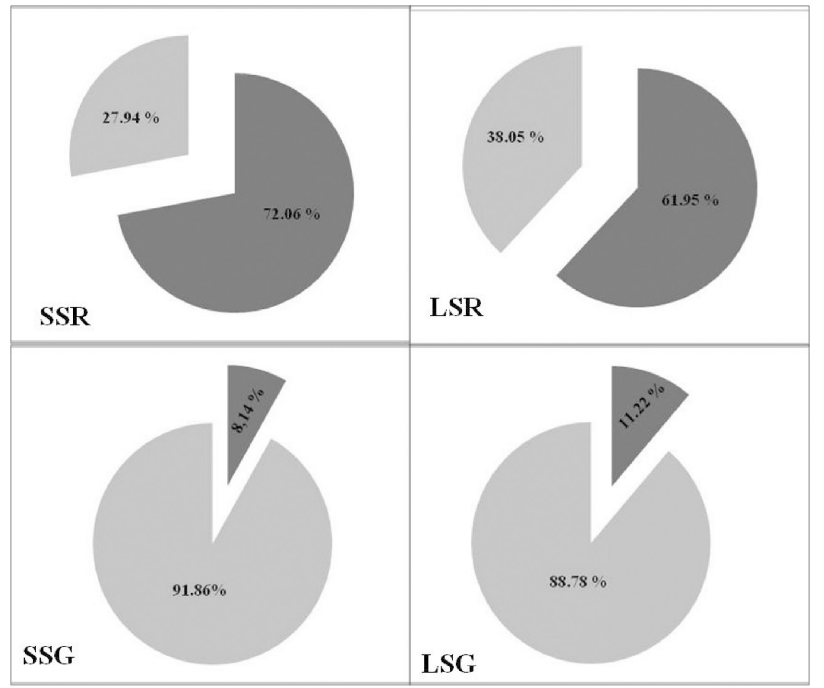

Immobilized \% $\quad$ Suspended $\%$

Fig. 3 -Immobilization percentage of the bioreactors
It is obvious from the immobilization measurements and SEM analysis that the glass beads were favorable in terms of cell immobilization (Figures 4 and 5). Although the immobilized cell culture was dominant in each bioreactor, suspended microorganisms were also observed in the void volumes of the reactors.

\section{Biohydrogen production by immobilized bioreactors}

In terms of daily hydrogen production volume, SSR material had the highest production $\left(418 \mathrm{~mL} \mathrm{H}_{2} \mathrm{~d}^{-1}\right)$ at $1.5 \mathrm{~h}$ HRT value. LSG and SSG materials also produced significantly high hydrogen volumes (403 $\mathrm{mL} \mathrm{H}_{2} \mathrm{~d}^{-1}$ and $302 \mathrm{~mL} \mathrm{H}_{2} \mathrm{~d}^{-1}$, respectively) at $3 \mathrm{~h}$ HRT, which is twice as much compared to the SSR reactor (Figure 2). Figure 2 also shows that longer HRT values resulted in lower hydrogen production for all reactor configurations, except for the
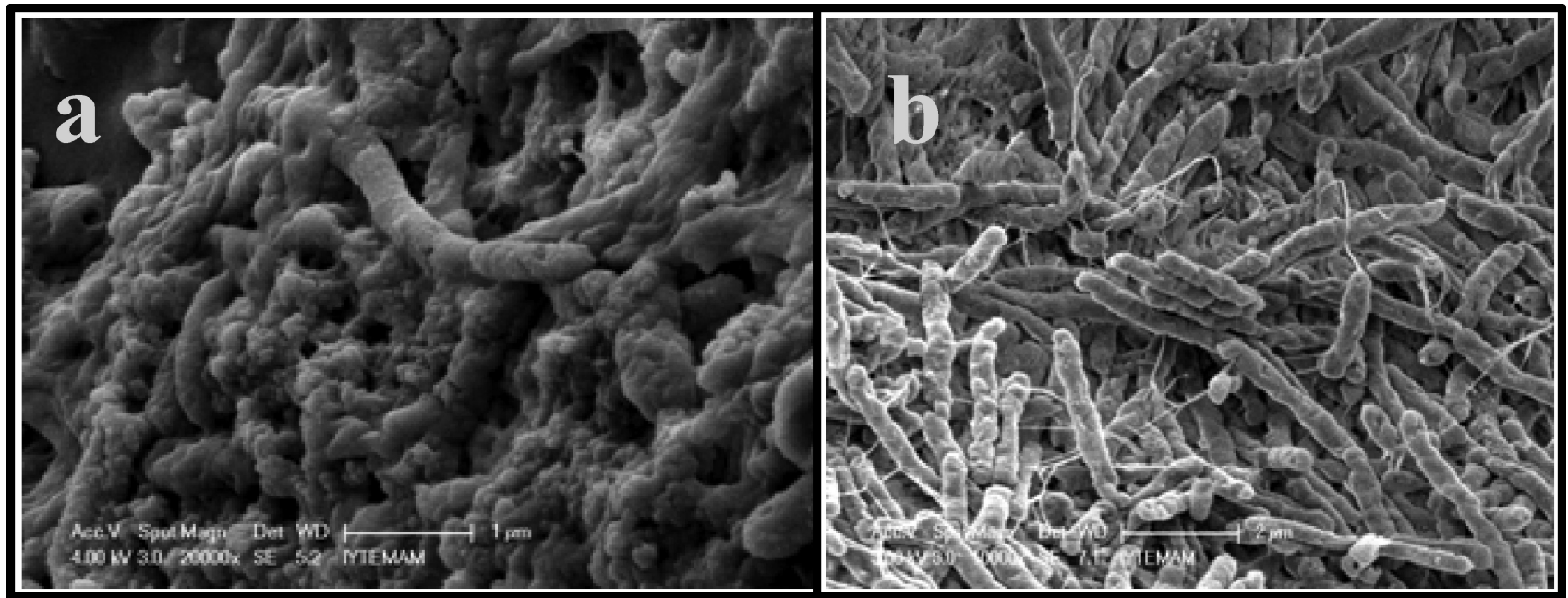

Fig. 4 - Scanning electron micrographs of (a) LS glass bead immobilized bioreactor after biohydrogen production, $1 \mu \mathrm{m}$ scale (b) SS glass bead immobilized bioreactor after biohydrogen production, 2 um scale

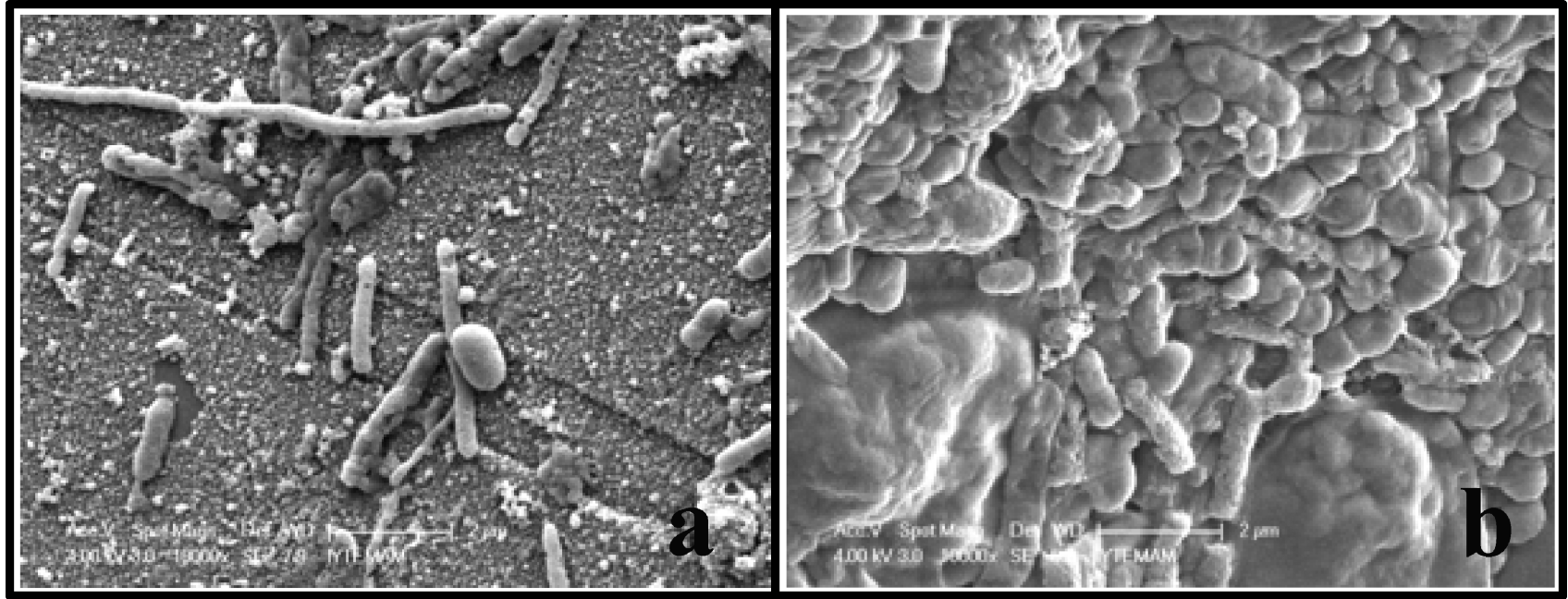

Fig. 5 - Scanning electron micrographs of (a) SS Raschig ring immobilized bioreactor after biohydrogen production, $2 \mu \mathrm{m}$ scale (b) LS Raschig ring immobilized bioreactor after biohydrogen production, 2 um scale 
Table 1 -Hydrogen yields and volumetric hydrogen production rates of the bioreactors

\begin{tabular}{|c|c|c|c|c|c|c|c|c|c|c|}
\hline \multirow{2}{*}{$\begin{array}{l}\text { HRT } \\
(\mathrm{h})\end{array}$} & \multicolumn{5}{|c|}{$\begin{array}{l}\text { Hydrogen yields } \\
\left(\mathrm{mL} \mathrm{H}_{2} \mathrm{~g}^{-1} \text { sucrose }\right)\end{array}$} & \multicolumn{5}{|c|}{$\begin{array}{l}\text { Volumetric hydrogen production rates } \\
\left(\mathrm{L} \mathrm{H}_{2} \mathrm{~L}^{-1} \text { reactor day }{ }^{-1}\right)\end{array}$} \\
\hline & $\begin{array}{l}\text { SS Glass } \\
\text { bead }\end{array}$ & $\begin{array}{l}\text { LS Glass } \\
\text { bead }\end{array}$ & $\begin{array}{l}\text { LS Raschig } \\
\text { ring }\end{array}$ & $\begin{array}{c}\text { SS Raschig } \\
\text { ring }\end{array}$ & CSTR & $\begin{array}{l}\text { SS Glass } \\
\text { bead }\end{array}$ & $\begin{array}{l}\text { LS Glass } \\
\text { bead }\end{array}$ & $\begin{array}{l}\text { LS Raschig } \\
\text { ring }\end{array}$ & $\begin{array}{l}\text { SS Raschig } \\
\text { ring }\end{array}$ & CSTR \\
\hline 1.5 & 445 & 567 & 36 & 1066 & 0 & 2.17 & 1.81 & 0.13 & 2.09 & 0.00 \\
\hline 3 & 389 & 566 & 33 & 402 & 0 & 2.39 & 2.98 & 0.23 & 1.30 & 0.00 \\
\hline 6 & 283 & 279 & 20 & 878 & 0 & 1.45 & 1.46 & 0.30 & 1.51 & 0.00 \\
\hline 12 & 362 & 221 & 11 & 68 & 16 & 1.59 & 1.46 & 0.03 & 0.73 & 0.02 \\
\hline 24 & 310 & 413 & 37 & 47 & 87 & 1.81 & 1.80 & 0.05 & 0.48 & 0.5 \\
\hline
\end{tabular}

CSTR type reactor. Hydrogen production in the CSTR reactor did not start until HRT had increased to $12 \mathrm{~h}$. Even at HRT of $24 \mathrm{~h}$, the hydrogen production rate in the CSTR reactor $\left(0.5 \mathrm{~L} \mathrm{H}_{2} \mathrm{~L}_{\text {reactor }}{ }^{-1} \mathrm{~d}^{-1}\right)$ was almost 6 times lower than that in the LSG reactor $\left(2.98 \mathrm{~L} \mathrm{H}_{2} \mathrm{~L}_{\text {reactor }}^{-1} \mathrm{~d}^{-1}\right)$.

The hydrogen content of the headspace in each reactor varied between $30-55 \%$, which is in accordance with literature ${ }^{17}$. The best $\mathrm{H}_{2}$ content in terms of $\%$ was $54 \%$ obtained from SSG at $3 \mathrm{~h}$ HRT. The glass beads support matrices showed better hydrogen concentration values than the Raschig rings. The CSTR reactor experiments, on the other hand, showed fluctuating hydrogen content in the headspace.

Hydrogen yields per unit amount of substrate were found to be $445 \mathrm{~mL} \mathrm{H} \mathrm{g}^{-1}$ sucrose used for SSG, and $567 \mathrm{~mL} \mathrm{H}_{2} \mathrm{~g}^{-1}$ sucrose for LSG at $1.5 \mathrm{~h}$ HRT. SSR had a hydrogen yield of $1066 \mathrm{~mL} \mathrm{H}_{2} \mathrm{~g}^{-1}$ sucrose, whereas LSR had a $36 \mathrm{~mL} \mathrm{H}_{2} \mathrm{~g}^{-1}$ sucrose productivity at $1.5 \mathrm{~h}$ HRT (Table 1). Except the LSR bioreactor with immobilized biomass, cell immobilization provided higher hydrogen yields in comparison to the CSTR type bioreactor at the same HRT values. Hydrogen production in the LSR reactor was low because this reactor had the lowest cell immobilization and the suspended cell concentration in the voids of the reactor was high.

As shown in Table 2, at $1.5 \mathrm{~h}$ HRT, the SSR packed bioreactor had the highest $k$ value (1.26) which was also the same as the $\mathrm{H}_{2}$ yields. Glass beads $k$ values are proportional to hydrogen yields. The $k$ values for CSTR at lower HRTs could not be monitored because of zero sugar consumption. Considering the $k$ values of CSTR, the best hydrogen production was at $24 \mathrm{~h}$ HRT, which was obtained in our study.

In biohydrogen production studies, the hydrogen yield per mole of sucrose consumed is the efficiency parameter to be discussed. Lin et al. ${ }^{23} \mathrm{ob}-$ tained 4.98 mole $_{2}$ mole $^{-1}$ sucrose at $8 \mathrm{~h}$ HRT with granular mixed cultures. Li et al. ${ }^{24}$ reported a hydrogen yield of 3.03 mole $\mathrm{H}_{2}$ mole $^{-1}$ sucrose at $0.5 \mathrm{~h}$ HRT with a spherical activated carbon immobilized
Table $2-k$ values (Michaelis Menten kinetics) of the packed plug flow bioreactors depending on the amount of sucrose consumed

\begin{tabular}{c|c|c|c|c|c}
\hline$t(\mathrm{HRT})$ & $k_{\mathrm{CSTR}}$ & $k_{\mathrm{LSR}}$ & $k_{\mathrm{SSR}}$ & $k_{\mathrm{LSG}}$ & $k_{\mathrm{SSG}}$ \\
\hline 1.5 & 0.00 & 0.92 & 1.26 & 0.61 & 0.36 \\
3 & 0.00 & 0.54 & 0.54 & 0.27 & 0.31 \\
6 & 0.08 & 0.20 & 0.15 & 0.17 & 0.13 \\
12 & 0.01 & 0.08 & 0.06 & 0.05 & 0.07 \\
24 & 2.04 & 0.04 & 0.02 & 0.03 & 0.03 \\
\hline
\end{tabular}

bioreactor, while they obtained 2.74 mole $\mathrm{H}_{2}$ mole $^{-1}$ sucrose in the same conditions with a cylindrical activated carbon immobilized bioreactor. In our study, SSR hydrogen yield per mole of sucrose consumed was $2.91 \mathrm{~mole}_{2}$ mole $^{-1}$ sucrose at $1.5 \mathrm{~h} \mathrm{HRT}$, and this value was 2.47 mole $\mathrm{H}_{2}$ mole $^{-1}$ sucrose at the same HRT conditions for SSG support material.

Our study showed that glass bead materials are more efficient than the Raschig rings in terms of volumetric hydrogen production rates (VHPR). The CSTR type suspended cell culture was unable to compete with immobilized bioreactors. The VHPR values for CSTR was only significant at $24 \mathrm{~h} \mathrm{HRT}$; however, with decreasing HRT values, the hydrogen yield and VHPR of CSTR were zero. The best VHPR value achieved with the LSG packed bioreactor at $3 \mathrm{~h}$ HRT was $2.98 \mathrm{~L} \mathrm{H}_{2} \mathrm{~L}^{-1} \mathrm{~d}^{-1}$, followed by the SSG reactor (HRT $2.39 \mathrm{~L} \mathrm{H}_{2}^{2} \mathrm{~L}^{-1}$ reactor $\mathrm{d}^{-1}$ ). Under mesophilic conditions at $1.5 \mathrm{~h}$ HRT, Chang et al. ${ }^{25}$ reported $1.32 \mathrm{~L} \mathrm{H}_{2} \mathrm{~L}^{-1}$ reactor $\mathrm{d}^{-1}$ with activated carbon as support material. In our study, the SSG packed reactor showed $64 \%$ higher hydrogen production $\left(2.17 \mathrm{~L} \mathrm{H}_{2} \mathrm{~L}_{\text {reactor }}^{-1} \mathrm{~d}^{-1}\right)$ at the same HRT condition.

\section{Conclusion}

Raschig rings and glass beads were successfully used for cell immobilization in a packed bed bioreactor. Cell washout during high organic loading and low HRT values was seemingly avoided. The yield and efficiency of the immobilized cell packed 
bed reactor were much better compared to the suspended cell bioreactor, while biohydrogen production was significantly enhanced. Among the immobilization materials used in this study, glass beads resulted in higher hydrogen production than Raschig rings. Both glass beads and Raschig rings were promising immobilization materials for scaleup purposes. It is obvious that dark-fermentative biohydrogen production with immobilized cell reactor configuration provides promising advantages for a sustainable hydrogen economy.

\section{ACKNOWLEDGMENTS}

The authors wish to thank TUBITAK-CAYDAG for financially supporting this study under the grant No. 109Y004. The data presented in this article were produced within the project above, however, it is only the authors of this article who are responsible for the results and discussions indicated herein.

\section{References}

1. Das, D., Veziroğlu, T. N., Hydrogen production by biological processes. A survey of literature, Int. J. Hydrogen Energy 26 (2001) 12. doi: http://dx.doi.org/10.1016/S0360-3199(00)00058-6

2. Keskin, T., Aksöyek, E., Azbar, N., Comparative analysis of thermophilic immobilized biohydrogen production using packed materials of ceramic ring and pumice stone, Int. J. Hydrogen Energy 36 (2011) 15160. doi: http://dx.doi.org/10.1016/j.ijhydene.2011.08.078

3. Kapdan, I. K., Kargl, F., Bio-hydrogen production from waste materials, Enzyme Microb. Technol. 38(5) (2006) 569. doi: http://dx.doi.org/10.1016/j.enzmictec.2005.09.015

4. Zhang, Z. P., Show, Y. K., Tay, J., Lee, D., Enhanced continuous biohydrogen production by immobilized anaerobic microflora, Energy Fuels 22 (2008) 87. doi: http://dx.doi.org/10.1021/ef700272m

5. Wu, S. Y., Lin, C. N., Chang, J. S., Biohydrogen production with anaerobic sludge immobilized by ethylene-vinyl acetate copolymer, Int J Hydrogen Energy. 30(13-14) (2005) 1375.

doi: http://dx.doi.org/10.1016/j.ijhydene.2004.09.011

6. Wang, J., Wan, W., Comparison of different pretreatment methods for enriching hydrogen- producing bacteria from digested sludge. Int. J. Hydrogen Energy 3(12) (2008) 2934.

doi: http://dx.doi.org/10.1016/j.ijhydene.2008.03.048

7. Cheong, D. Y., Hansen, C. L., Bacterial stress enrichment enhances anaerobic hydrogen production in cattle manure sludge. Appl. Microbiol. Biotechnol. 72(4) (2006) 635. doi: http://dx.doi.org/10.1007/s00253-006-0313-x

8. $H u, B$., Chen, S., Pretreatment of methanogenic granules for immobilized hydrogen fermentation, Int. J. Hydrogen Energy, 32(15) (2007) 3266. doi: http://dx.doi.org/10.1016/j.ijhydene.2007.03.005

9. Zhu, H. G., Beland, M., Evaluation of alternative methods of preparing hydrogen producing seeds from digested wastewater sludge, Int. J. Hydrogen Energy 31(14) (2006) 1980.

doi: http://dx.doi.org/10.1016/j.ijhydene.2006.01.019
10. Wang, J., Wan, W., Experimental design methods for fermentative hydrogen production: A review, Int. J. Hydrogen Energy 34 (2009) 35. doi: http://dx.doi.org/10.1016/j.ijhydene.2008.10.008

11. Schiweck, H., Clarke, M., Pollach, G., Ullmann's Encyclopedia of Industrial Chemistry: Sugar; 2007.

12. $M u, Y$., $Y u, H$., Biological hydrogen production in a UASB reactor with granules, Biotech. and Bioeng. 94 (2006) 980. doi: http://dx.doi.org/10.1002/bit.20924

13. Wunschiers, R., Lindblad, P., Hydrogen in education- a biological approach, Int. J. Hydrogen Energy 27 (2002) 1131. doi: http://dx.doi.org/10.1016/S0360-3199(02)00098-8

14. Hawkes, F. R., Hussy, I., Kyazze, G., Dinsdale, R., Hawkes, $D$. $L$., Continuous dark fermentative hydrogen production by mesophilic microflora: principles and progress, Int. J. Hydrogen Energy 32 (2007) 172. doi: http://dx.doi.org/10.1016/j.ijhydene.2006.08.014

15. Yokoi, H., Meada, Y., Hirose, J., Hayashi, S., Takasaki, Y., $\mathrm{H}_{2}$ production by immobilized cells of Clostridium butyricum on porous glass beads, Biotechnol. Techn. 11(6) (1997) 431. doi: http://dx.doi.org/10.1023/A:1018429109020

16. Azbar, N., ÇetinkayaDokgöz, F. T., Keskin, T., Korkmaz, K. S., Syed, H. M., Continuous fermentative hydrogen production from cheese whey wastewater under thermophilic anaerobic conditions, Int. J. Hydrogen Energy 34(17) (2009) 7441. doi: http://dx.doi.org/10.1016/j.ijhydene.2009.04.032

17. Oh, S., Iyer, P., Bruns, M. A., Logan, B. E., Biological hydrogen production using a membrane bioreactor, Biotech. and Bioeng. 87(1) (2004) 119. doi: http://dx.doi.org/10.1002/bit.20127

18. Argun, H., Kargl, F., Kapdan, I., Hydrogen production by combined dark and light fermentation of ground wheat solution, Int. J. Hydrogen Energy 34(10) (2009) 4305. doi: http://dx.doi.org/10.1016/j.ijhydene.2009.03.033

19. Mohan, S. V., Babu, V. L., Sarma, P. N., Effect of various pretreatment methods on anaerobic mixed microflora to enhance biohydrogen production utilizing dairy wastewater as substrate, Bioresource Tech. 99 (2008) 59. doi: http://dx.doi.org/10.1016/j.biortech.2006.12.004

20. Chairattanamanokorn, P., Penthamkeerati, P., Reungsang, A., Lo, Y. C., Lu, W. B., Chang, J. S., Production of biohydrogen from hydrolyzed bagasse with thermally preheated sludge, Int. J. Hydrogen Energy 34(18) (2009) 7612. doi: http://dx.doi.org/10.1016/j.ijhydene.2009.07.034

21. Vijayaraghavan, K., Ahmad, D., Khairil Bin, I. M., Naemmah Binti Herman, H., Isolation of hydrogen generating microflora from cow dung for seeding anaerobic digester, Int. J. Hydrogen Energy 31(6) (2006) 708.

22. Sinha, P., Pandey, A. An evaluative report and challenges for fermentative biohydrogen production, Int. J. Hydrogen Energy 36 (2011) 7460. doi: http://dx.doi.org/10.1016/j.ijhydene.2011.03.077

23. Lin, C., Lee, C., Tseng, I., Shiao, I. Z., Biohydrogen production from sucrose using base-enriched anaerobic mixed microflora, Process Biochem. 41(4) (2006) 915. doi: http://dx.doi.org/10.1016/j.procbio.2005.10.010

24. Li, C., Fang, H.H. P., Inhibition of heavy metals on fermentative hydrogen production by granular sludge, Chemosphere 67(4) (2007) 668. doi: http://dx.doi.org/10.1016/j.chemosphere.2006.11.005

25. Chang, J., Lee, K., Lin, P., Biohydrogen production with fixed-bed bioreactors, Int. J. Hydrogen Energy 27 (2002) 1167. doi: http://dx.doi.org/10.1016/S0360-3199(02)00130-1 